\title{
OBTAINING OF SOME GRAFTED WATERMELON SEEDLINGS (CITRULLUS LANATUS SCION X CUCUMIS METULIFERUS, BENICASA HISPIDA AND LAGENARIA SICERARIA ROOTSTOCKS)
}

\author{
Mădălina Doltu ${ }^{1 *}$, Dorin Sora ${ }^{1}$, Marian Bogoescu ${ }^{1}$, Ioana Cucu ${ }^{1}$ \\ ${ }^{1}$ Institute of Research and Development for Industrialization and Marketing of Horticultural Products - Horting, \\ Drumul Gilăului, no. 5 N, District 4, 041715, Bucharest, Romania
}

\section{Current Trends in}

\section{Natural Sciences}

\begin{abstract}
The watermelons are valuable vegetables. The research aim has been to establish of the technological stages for producing of Dutch and Romanian scion and rootstock seedlings from Citrullus lanatus, Cucumis metuliferus, Benicasa hispida and Lagenaria siceraria, to obtain some compatible phenotypes to grafting. The experience was carried out on a cultivars collection consisting from a Dutch watermelon scion (Baronesa F1 hybrid, Sugar baby type), two Romanian rootstocks (Kiwano and Zefir) and a Dutch rootstock (Pelops F1 hybrid). The scion and rootstock diameters have been correlated for manual grafting, cutting with a cotyledonous leaf and method by splice in silicone clip. The technological stages for obtaining of grafted watermelons have been established for the researched genotypes. These genotypic combinations ( $C$. lanatus $x$ C. metuliferus, C. lanatus $x$ B. hispida, C. lanatus $x$ L. siceraria) have been compatible for watermelon grafting in south area of Romania.
\end{abstract}

Keywords: compatibility, cucurbits, grafting

\section{INTRODUCTION}

The watermelons are valuable vegetables, with big share in Romanian crops.

Depending on the cultivar, watermelon chemical composition consists of 89-94\% water, 7-11\% sugar, $0.2 \%$ fats, $0.5 \%$ protein, vitamins $(\mathrm{A}, \mathrm{B}, \mathrm{C}, \mathrm{H}, \mathrm{PP})$ and minerals $(2,5 \mathrm{mg}$ potassium, $0.2 \mathrm{mg}$ iron, $7 \mathrm{mg}$ calcium, zinc); its energetical value is 26-29 calories/100 g (Popescu, 2012) or 95\% water, 3-6.9\% sugar, $0.5-0.8 \%$ protein, $0,2 \%$ fats, 0,3-0,52\% vitamins (Lagunovschi-Luchian and Vînătoru, 2016).

The grafting is a vegetative multiplication method that induces or improves some qualities of the plants (vigor, resistance to soil diseases and pests, resistance to abiotic factors, quantity and quality of fruit production) (Sora, 2018).

In theory, the graft is the union of two or more pieces of living tissue, which once joined together develop as a single plant. This combination of desirable characteristics consists in the removal of the buds of a plant that is called graft and the root that is provided by a plant that is called rootstock. (Álvarez-Hernández, 2019).

The thickness of the scion seedling at the cut surface should correspond with the section thickness of rootstock section and the performance of grafting in young seedling stage, leads to increase of the success chances (Bogoescu et al., 2009). 


\begin{tabular}{lcr}
\hline & $\begin{array}{c}\text { Current Trends in Natural Sciences } \\
\text { Vol. 9, Issue 18, pp. 86-91, 2020 }\end{array}$ \\
& $\begin{array}{c}\text { https://doi.org/10.47068/ctns.2020.v9i18.012 } \\
\text { Current Trends in Natural Sciences (on-line) }\end{array}$ & Current Trends in Natural Sciences (CD-Rom) \\
ISSN: 2284-953X & ISSN: 2284-9521 \\
ISSN-L: 2284-9521 & ISSN-L: 2284-9521 \\
\hline
\end{tabular}

The plant diameters are correlated for an optimal grafting so: the scion in the phenophasis with a true leaf and the rootstock in the phenophasis with cotyledonous leaves.

The research aim has been to establish of the technological stages for producing of Dutch and Romanian scion and rootstock seedlings from Citrullus lanatus (scion) and Cucumis metuliferus, Benicasa hispida and Lagenaria siceraria (rootstocks), to obtain some compatible phenotypes to grafting.

\section{MATERIALS AND METHODS}

This research has been conducted in a grafted seedling greenhouse from the Horting Institute, Bucharest (Figure 1).

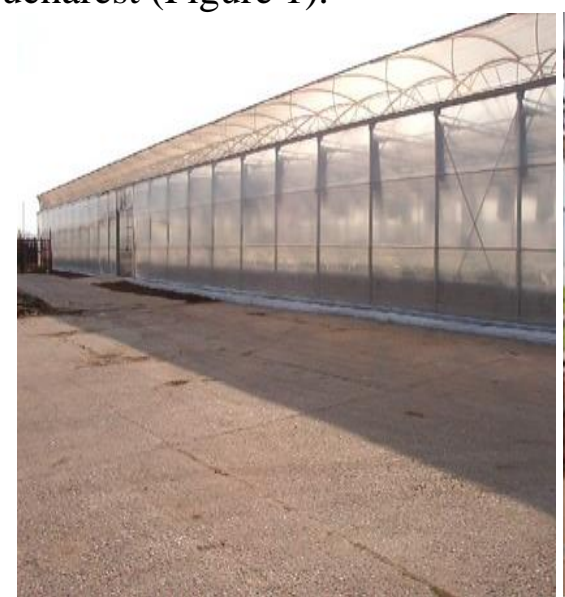

a) greenhouse

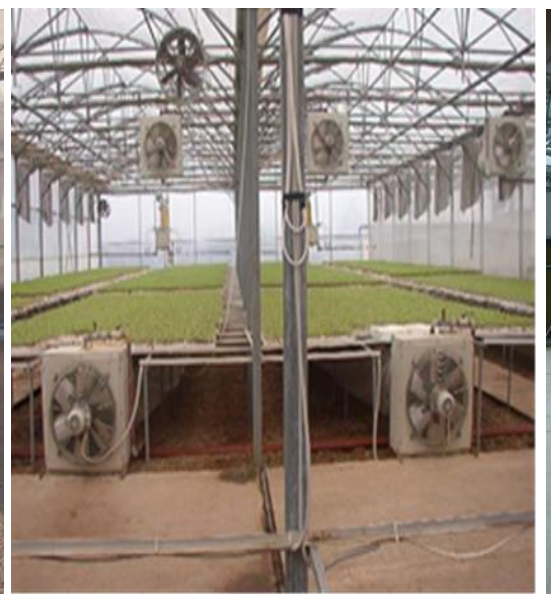

b) growing room

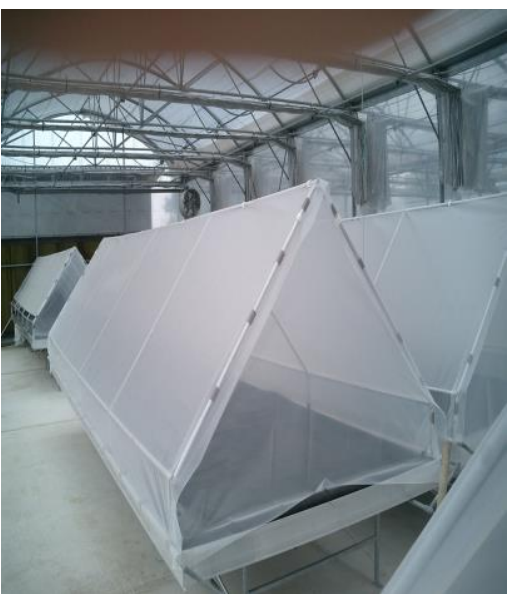

c) callusing tunnel

Figure 1. Seedling greenhouse from Horting Institute Bucharest

This research experience was carried out on a cultivars collection consisting from a Dutch watermelon scion (Baronesa F1 hybrid $-C$. lanatus, Sugar baby type), two Romanian rootstocks (Kiwano $-C$. metuliferus and Zefir $-B$. hispida) and a Dutch rootstock (Pelops F1 hybrid $-L$. siceraria) (Figure 2).

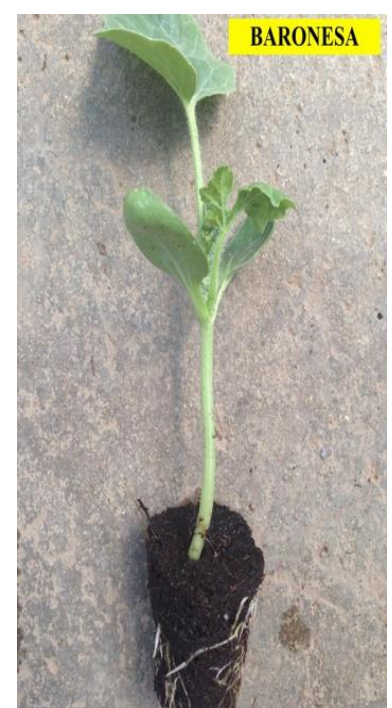

(1)

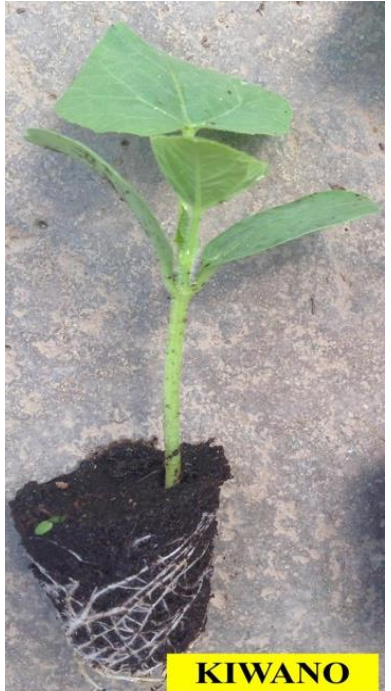

(2)

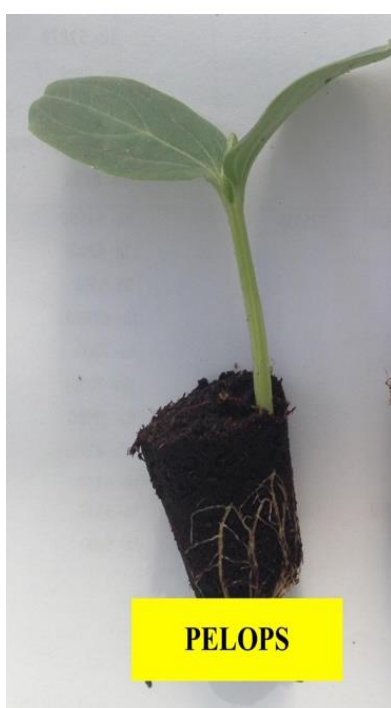

(3)

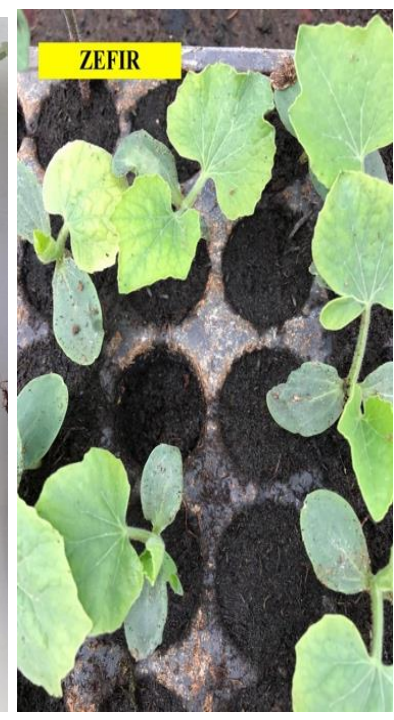

(4)

Figure 2. Biological material: scion (1) and rootstocks $(2,3,4)$ 
The experimental scheme used was made up from three variants:
V1 - Baronesa x Pelops,
V2 - Baronesa x Kiwano,
V3 - Baronesa x Zefir.

The plant diameters have been correlated for manual grafting, cutting with a cotyledonous leaf for all rootstocks and method by splice in silicone clip.

The technological stages for obtaining of grafted watermelons have been established for the researched genotypes.

The technological parameters for achieving a microclimate necessary for the callusing process of the grafted seedlings in the first 7 days after the grafting were established as follows:

- $23^{\circ} \mathrm{C}$ temperature,

- $\quad 98 \%$ relative atmospheric humidity,

- light intensity from $\leq 10 \mathrm{lux} / \mathrm{sqm}$ between first day to fourth day and 3000-4000 lux/sqm between fifth day to seventh day.

The characteristics evaluated on scion and rootstocks in this research were stem diameter $(\mathrm{mm})$, scion length $(\mathrm{cm})$ and the yield (\%) / callusing degree (0-3) of the grafted plants.

The scale between 0 to 3 recommended by Guimarães et al., 2019 was used to assess the callusing degree, respectively the success of the grafting; the assignment of the rootstock / scion attachment degrees was achieved as follows:

- 0 (without union),

- 1 (small union),

- 2 (partial union),

- 3 (complete union).

\section{RESULTS AND DISCUSSIONS}

The scion and rootstock diameters have been correlated for manual grafting and method by splice in silicone clip.

Obtaining of grafted watermelon seedlings has involved these phases:

- sowing rootstocks and scion - in nutritive substrate (peat with grain size $0-10 \mathrm{~mm}$ and $24 \mathrm{ml} / \mathrm{plant}$ root volume). After sowing, the plants are cultivated in classic conditions for ungrafted cucurbit seedlings.

The germination conditions for all scion and rootstock plants have been:

- 28-30 ${ }^{\circ} \mathrm{C}$ temperature,

- $90 \%$ relative atmospheric humidity,

- EC between1,5 - 1,8 mS,

- $\mathrm{pH}$ between $6,0-6,5$.

After Bogoescu et al., 2009, required germination conditions are

- temperature: $25-27^{\circ} \mathrm{C}$,

- relative atmospheric humidity: $80 \%$,

- EC: $1,5-1,8 \mathrm{mS}$,

- pH: $6,0-6,5$,

- light intensity: 4500lux/mp, between 05.00 - 18.00 hours.

- preparing for grafting with different materials (silicone clips, razor blades),

- grafting - method utilized has been in simple copulation by performing a cut of rootstock with one-cotyledon and the scion at $45^{\circ}$. A silicone clip has been applied over the cut and placed on rootstock and scion stems (Figure 3). 


\section{Current Trends in Natural Sciences}

Vol. 9, Issue 18, pp. 86-91, 2020

https://doi.org/10.47068/ctns.2020.v9i18.012

Current Trends in Natural Sciences (on-line)

ISSN: 2284-953X

Current Trends in Natural Sciences (CD-Rom)

ISSN-L: 2284-952

ISSN: 2284-952

ISSN-L: 2284-9521

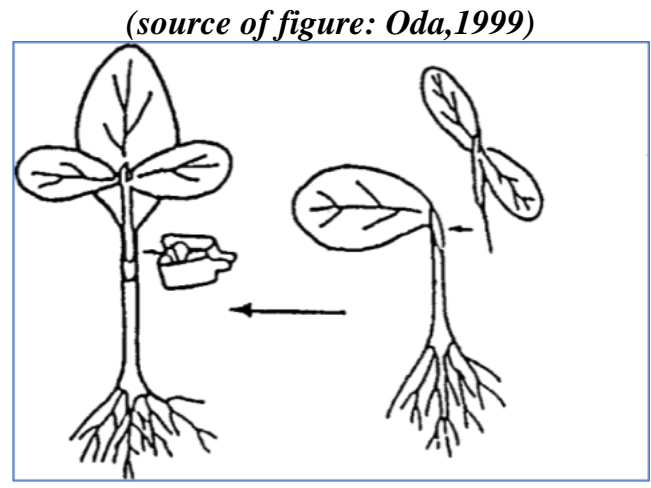

Figure 3. Cucurbit grafting method with one-cotyledon

- forming of callus for 7 days - in polyethylen tunnel with specific microclimate conditions $\left(23^{\circ} \mathrm{C}\right.$ temperature and $98 \%$ relative air humidity); closed tunnel for 5 days,

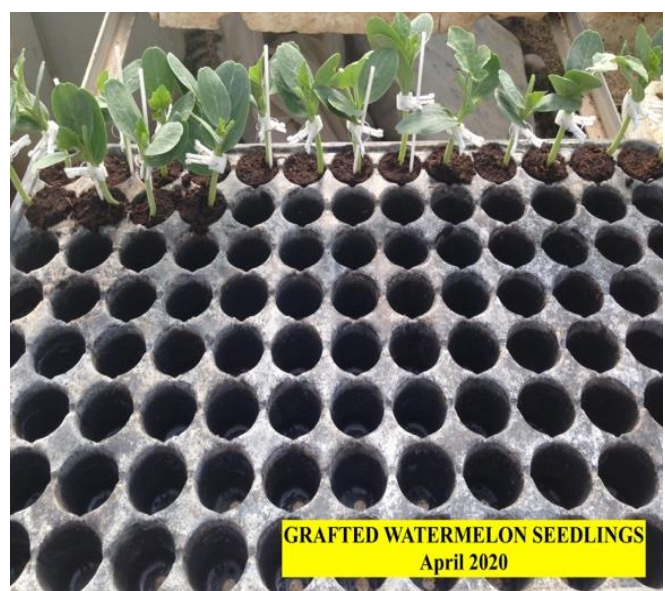

1) first day

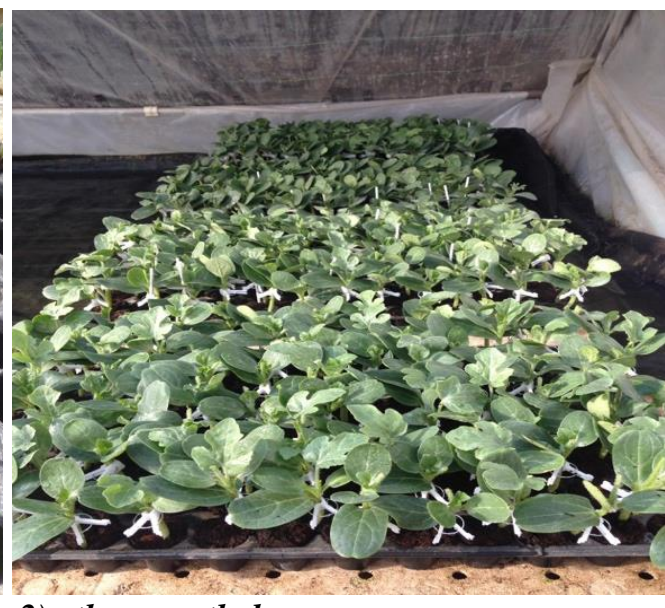

2) the seventh day

Figure 4. Grafted watermelon in polyethylen tunnel

- transferring of grafted watermelon seedlings from the tunnel in the growing greenhouse.

The transfer has been made starting with the eighth day from grafting in a growig room with watermelon specific microclimate conditions.

The technological stages for obtaining of grafted watermelons have been established for the researched genotypes according to the data from table 1 .

Table 1. Technological stages of watermelon grafting (calendar data for the year 2020)

\begin{tabular}{c|c|c|c} 
Variant & Combination (scion x rootstock) & Sowing & Grafting \\
\hline V1 & Baronesa x Pelops & March, 31 / April, 9 & April, 22 \\
\hline V2 & Baronesa x Kivano & April, 15 / April, 15 & April, 27 \\
V3 & Baronesa x Zefir & April, 15 / April, 15 & April, 27
\end{tabular}

The Baronesa scion have been sowing to March, 31 and to April, 15. The Pelops rootstock have been sowing to April, 9 and the Zefir and Kiwano rootstocks to April, 15. 


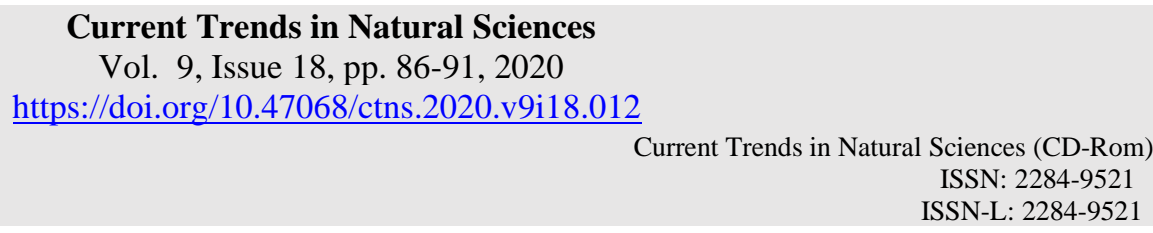

Current Trends in Natural Sciences (on-line)

The grafting have been established to April, 22 for a genotypic combination (Baronesa $\mathrm{x}$ Pelops) and to April, 27 for two genotypic combinations (Baronesa x Zefir and Baronesa x Kiwano). The characteristics evaluated on the biological material (scion and rootstocks) are shown in table 2.

Table 2. Biological characteristics and yield / callusing degree of grafted plants

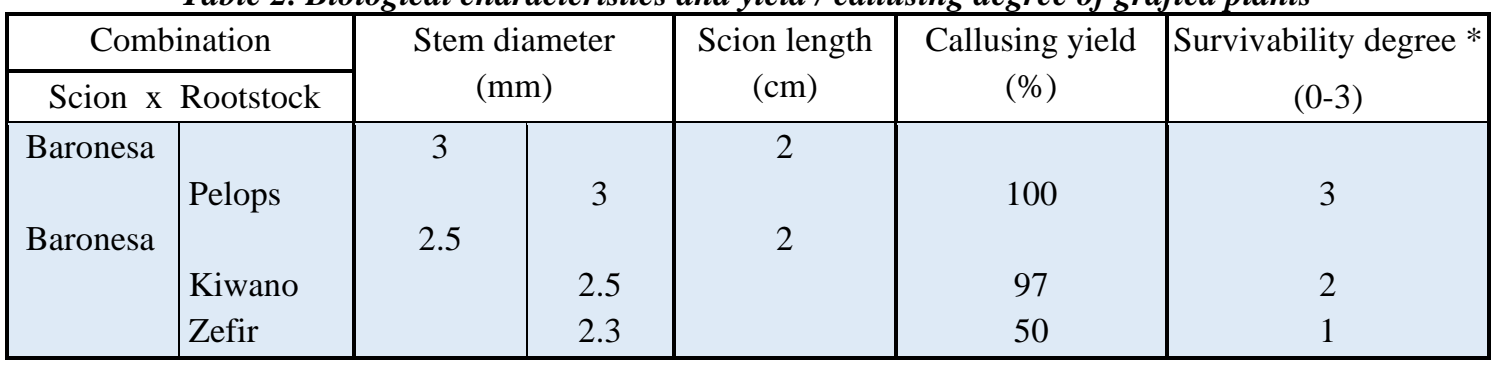

*scale (0-3) by Guimarães et al., 2019.

The stem diameters have been the absolute compatible onto two rootstocks $(3 / 3 \mathrm{~cm}$ onto Pelops rootstock and 2.5/2.5 cm onto Kiwano rootstock), but less compatible onto a rootstock (2.5/2.3 onto Zefir) to grafting day.

The length of the Baroneasa watermelon scion has been $2 \mathrm{~cm}$ onto all rootstocks.

The survivability after grafting depends on this compatibility between stem diameters, so the callusing yield (\%)/success or degree (0-3) have been so: 100/3 onto Pelops, 97/2 onto Kiwano, $50 / 1$ onto Zefir.

The stem tissues of scion must overlap perfectly onto the stem tissues of rootstock (Figure 5).

After Bogoescu et al., 2009, the thickness of the scion seedling at the cut surface should correspond with the section thickness of rootstock section.

The essential aspect of compatibility between diameters is stressed and other researchers (Bogoescu et al., 2009; McAvoy, 2005 - this researchers are quoted by Doltu et al., 2014).

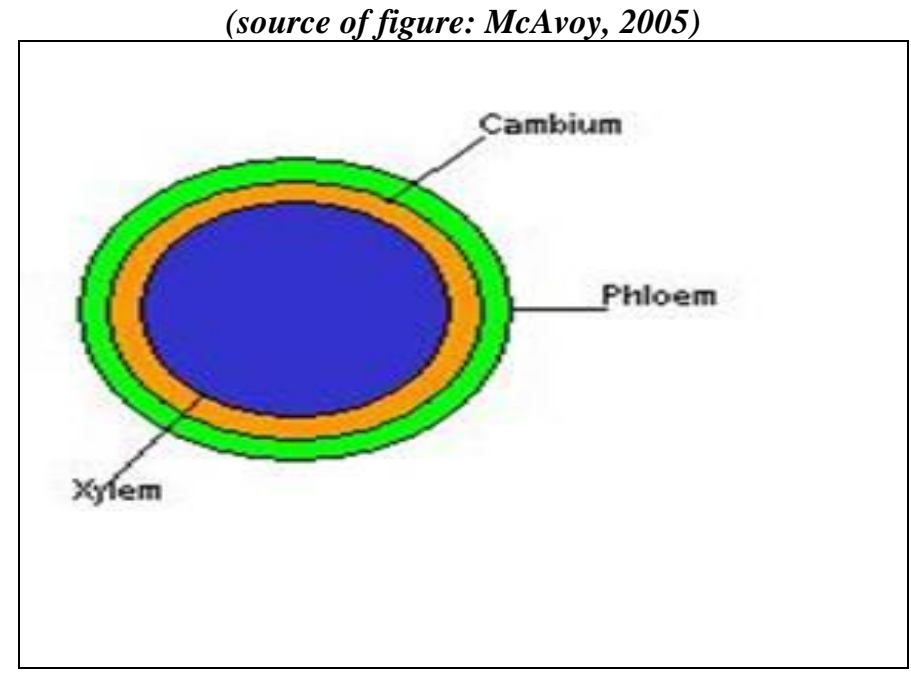

Figure 5. Stem tissues (cross-sectional) 


\section{Current Trends in Natural Sciences}

Vol. 9, Issue 18, pp. 86-91, 2020

https://doi.org/10.47068/ctns.2020.v9i18.012

Current Trends in Natural Sciences (on-line)

ISSN: 2284-953X

Current Trends in Natural Sciences (CD-Rom)

ISSN: 2284-9521

ISSN-L: 2284-9521

ISSN-L: 2284-9521

\section{CONCLUSIONS}

For a optimal grafting, the Baronesa scion has been sown 9 days before the Pelops rootstock and the Baronesa scion and the Kiwano and Zefir rootsocks have been sown on the same day.

The technological parameters from the callusing tunnel have been established for the success and survivability of different combinations of grafted watermelons so: $23^{\circ} \mathrm{C}$ temperature, $98 \%$ relative atmospheric humidity, light intensity from $\leq 10 \mathrm{lux} / \mathrm{sqm}$ between first day to fourth day and 30004000 lux/sqm between fifth day to seventh day.

The survivability has been $100 \%$ onto Pelops, $97 \%$ onto Kiwano and $50 \%$ onto Zefir.

These genotypic combinations ( $C$. lanatus x $C$. metuliferus, $C$. lanatus $\times$ B. hispida, $C$. lanatus $\times$ L. siceraria) have been compatible for watermelon grafting to April, 22-27, in south area of Romania.

In conclusion, the use grafted watermelon seedlings, the researched genotypical combinations (Dutch scion - Baronesa x Dutch and Romanian rootstocks - Pelops, Kiwano, Zefir) may be recommended for grafting.

\section{ACKNOWLEDGEMENTS}

The data presented in this paper were obtained within the ADER 7.3.1./2019 Project, funded by the Sectorial National Plane of Research - Agriculture and Rural Development Ministry, Romania.

\section{REFERENCES}

Álvarez-Hernández, J.C. (2019). Grafting in Horticultural Crop Species: Effective Pest and Disease Management

Technique with Potential in Michoacan. Horticultural Crops. Hugues Kossi Baimey, Noureddine Hamamouch and Yao Adjiguita Kolombia.

Bogoescu, M., Doltu, M., Sora, D., Mohora, A., Iordache, B. (2009). Results on establishing the technology for obtaining the watermelons grafted seedlings. Bulletin UASVM, Horticulture Cluj-Napoca, 66(1), 397-403.

Doltu, M., Bogoescu, M., Sora, D. (2014). Establishment of technology for asexual multiplying by grafting of some cultivars of melons cultivated in Romania. Scientific Papers Series Horticulture USAMV Iaşi 57(2), 79-84.

Guimarães, M.A., Garcia, M.F.N., Tello, J.P.J., Lemos Neto, H.S., Lima Neto, B.P., Rabelo, J.S. (2019). Tomato grafting on rootstock of Jilo, Cocona and Jurubeba. Horticultura Brasileira, 37, 138-145.

Lagunovschi-Luchian, V., Vînătoru, C. (2016). Legumicultură [Vegetable]. Ed. ALPHA MDN Buzău.

McAvoy, R. (2005). Grafting Techniques For Greenhouse Tomatoes. Greenhouse Tomato Conference, University of Connecticut Cooperative Extension System, NESARE and UMass Extension.

Oda, M. (1999). Grafting of vegetables to improve greenhouse production. Food \& Fertilizer Technology Center, Taiwan.

Popescu, A. (2012). Research on Romania's watermelon and melon market. Scientific Papers Series Management, Economic Engineering in Agriculture and Rural Development, 12(4), 45-54.

Sora, D. (2019). Establishment of technological stages for obtaining of some grafted tomato seedlings (Dutch scion $\mathrm{x}$ Romanian rootstocks). Bulletin UASVM Horticulture Cluj-Napoca, 76(1), 143- 144. 